\title{
A study into the hub performance of Emirates, Etihad Airways and Qatar Airways and their competitive position against the major European hubbing airlines
}

\subsection{Introduction}

Traffic flows between East and West had traditionally been concentrated at European hubs. Travellers flying Eastbound and Westbound used to connect in airports such as London Heathrow, Paris Charles de Gaulle, Frankfurt or Amsterdam (Dennis, 2007; Bel and Fageda, 2010; Grimme, 2011; Hooper et al., 2011). However, the growth of the Middle East aviation business has led to the rise of new hubs in the region. The Gulf has invested heavily in the aviation business as it is regarded as an important asset for the development of the region, Gulf based airlines are challenging the European network carriers in their long-haul traffic segment. Emirates, Etihad and Qatar Airways, as the most important exponents of the rise of the Gulf, have engineered their bases to become important transfer points for passengers which are beginning to redirect and reshape the traditional traffic flows (O'Connell, 2006; Vespermann et al., 2008; Hooper et al., 2011, Murel and O'Connell, 2011; O'Connell, 2011). The aggressive rise of the Gulf carriers is putting the leadership of the European network carriers and their corresponding hubs under threat (Delfmann et al., 2005).

The centre of gravity of international transfer traffic is shifting towards the East, while this displacement is being driven by the Gulf carriers as a result of their effective hub-and-spoke mechanism which is one of the key foundation pillars underpinning their continued success (O'Connell, 2011; Hooper et al., 2011, Murel and O'Connell, 2011). Dresner et al. (2015) confirms that the Gulf carriers are structurally changing the flows of international traffic through their respective hubs which are consequently impacting European, Asian and US full service domiciled airlines. A report on airport connectivity by the Airport Council International (2014) reported the magnitude of the problem by announcing that most of the indirect connections out of Europe are still channelled via EU hubs, but their share has decreased by $10 \%$ over the last decade reflecting the pressure from competing hubs particularly emanating from Turkey and the Gulf. Meanwhile, Amadeus (2014) found that the number of International transfer travellers flying via Middle East hubs has increased by $79 \%$ over the last 5 years. Grosche and Klophaus (2015) have confirmed that the competition between European and Gulf hubs has intensified significantly over the last number of years.

There are no known quantitative studies pertaining to the hub performance of the three Gulf carriers, nor is there any research that assesses the connectivity of their hub-and-spoke mechanism or in comparing the connectivity between Gulf and the major European hubbing airlines. This study is designed to fill this gap while delivering a measurable approach to this important subject area through the application of the "weighted connectivity ratio" for a sample of Middle Eastern and European hubs.

\subsection{Literature Review}


The meteoric rise of the three major Gulf carriers is evident when considering that in 2006, they transported just over 27 million passengers, while this magnified 3.5 fold, reaching over 96 million passengers by 2015. Similarly the domiciled airport ensemble of Dubai, Abu Dhabi and Doha grew three-fold over the same time period accommodating 132 million passengers by 2015, comparable to the combined pairing of Chicago O'Hare and New York JFK (Flightglobal, 2016). The three Gulf incumbents have more widebody aircraft on order than the US and Chinese carriers combined and have big ambitions to become the world's next generation of super connectors. Many academic writings that underpin the operational success of Gulf carriers are associated with the dual impact of their transfer hub and geographical location that have allowed them to spread their network footprint so effectively (O'Connell, 2006; Vespermann et al., 2008; Grimme, 2011; Hooper et al., 2011; Murel and O'Connell, 2011; O'Connell, 2011; de Wit, 2014; Grosche and Klophaus, 2015). OAG analysis reveals the aggressive expansion profiles of the three Gulf carriers as they collectively offered around 51,500 flights to Europe in 2015, marking a $270 \%$ increase over 2005 figures, however due to the skewed portfolio of their widebody fleet, the number of seats increased by $360 \%$ from 3.6 million seats in 2005 to 16.7 million by 2015. Dubai became the third busiest route from the UK with 5.2 million passengers in 2014, while Doha ranks $41^{\text {st }}$, with 1.2 million passengers with Abu Dhabi ranked at $52^{\text {nd }}$ at 1 million (UK CAA, 2015). Dresner et al. (2015) conducted a rigorous study on the impact of Gulf carrier's on US carriers' passenger volumes from Q1 2003 to Q3 2011 and found that a 1\% growth in total Gulf carrier traffic to or from the US is associated with a less than $0.1 \%$ drop in U.S. carriers' international passenger traffic, which is negligible. However the associated benefits accruing to competition are abundant as it benefits the welfare of consumers, drives product innovation and operational reliability. OAG (2015) research outlines the fringe benefits accruing to other carriers as 730,743 passengers from the three Gulf carriers connected onto US carriers in 2014, equating to 2,000 passengers daily. Fan and Lingblad (2016) compared air fares between Singapore Airlines and Qatar Airways for four key city-pairs between Europe and Asia that required an intermediate stop through their respective hub and found that the fare provided by the Gulf carrier was lower in both economy and business class. These new innovative super connectors have: young fleets that are equipped with the newest generation of in-flight products; received numerous award winning customer service accolades; produced low unit operating costs; with strengthening brands; that are capitalising on their geocentric location by aggregating traffic from developed and emerging economies into their hubs and then redistributing this traffic globally. Their business model is setting the new gold standard for the industry.

A considerable amount of literature has been published on the measurement of network performance and hub connectivity, especially in Europe. In the 1990s and early 2000s, Dennis carried out an extensive study on the major European airlines' hubbing performance (Dennis, 1994a; Dennis, 1999; Dennis, 2001). Dennis (1994a) examined the effectiveness with which the main European carriers operated at their respective hubs. The research showed that KLM and Lufthansa provided the most effective hubbing operations at Amsterdam and Frankfurt respectively. Furthermore, the study pointed out that despite its optimal geographical position for a European hub and larger network, Air France at Paris Charles de Gaulle exhibited a low connectivity ratio as well as British Airways at London Heathrow. In a later study, Dennis (1999) investigated the competitive interactions between European hubs. While London 
Heathrow was found to be the dominant for services to North America, Asia, Middle East and Africa; Paris dominated the Latin America market at that time. Additionally, Brussels and Paris were identified as the most optimal location for a continental hub. The research also showed a poor coordination at London Heathrow that contrasted with good schedules at Amsterdam (KLM) and Zurich (Swissair). Later, Dennis (2001) analysed the developments of hubbing at European airports. The study showed that hubbing activity increased at the major airports between 1995 and 1999 and this strategy remained crucial for European carriers. Moreover, the author also examined the wave structure at the major hubs and pointed out how some airlines increased the number of waves, suggesting a six-wave pattern as the optimal structure for airlines in Europe.

Previously, Veldhuis (1997) had focused his research on Amsterdam Schiphol Airport. The study found that while total connectivity increased by 8\% annually from 1994 to 1996, the hub connectivity augmented by $34 \%$ as a result of the growth in average frequency and average time quality. Meanwhile, Rietveld and Brons (2001) also analysed the quality of hub-and-spoke networks of four large European airports namely Amsterdam, Frankfurt, London Heathrow and Paris Charles de Gaulle by measuring the effects of time table coordination. Similar to the findings of Dennis (1994a), the empirical results exhibited a higher value of flight coordination and shorter connecting times at Frankfurt and Amsterdam airport. By contrast, waiting times were longer at the largest airports which included London Heathrow and Paris Charles de Gaulle, contrary to what was expected, given the higher frequencies at these hubs.

Later, Burghouwt and Veldhuis (2006) analysed the competitive positon of hub airports for the transatlantic market. The study showed that US airports had a dominant position compared to European counterparts in terms of hub connectivity given the difference in market size. Furthermore, the research found that only $1 \%$ of the hub connectivity in the transatlantic market was provided by airlines which didn't belong to an alliance. Burghouwt (2007) examined the network performance of European airlines. The study demonstrated that several airlines implemented or reinforced a wave structure at their hubs during the period from 1990 to 2003 in consonance with Dennis (2001). In a later study, Burghouwt et al. (2008) focused on the position of Amsterdam's Schiphol airport and compared it to its competing hubs, similar to what Veldhius (1997) had done previously. The research identified the North America - Europe; Asia Pacific - Europe; and intra-European as the most important hub markets for the airport. Additionally, Frankfurt and Heathrow were found to be the most important competitors in line with previous research. Nevertheless, at other geographical submarkets other competing, hubs such as: Istanbul with Turkish Airlines; Dubai with Emirates; or Madrid with Iberia; also represented significant competition. Additionally, Malighetti et al. (2008) examined the connectivity of the European air transport network and confirmed that the four main hubs in Europe namely, Frankfurt, Paris CDG, London Heathrow and Amsterdam Schiphol were ranked as the world's leading hubs in terms of connectivity. However, London Stansted and Dublin were ranked among the top five airports in the European connectivity classification as they demonstrated a certain tendency towards a "self-help hubbing" strategy according to the authors. Suau-Sanchez and Burghouwt (2012) found that the network rationalization strategy of Iberia which concentrated its hub operations primarily at Madrid-Barajas airport created a multitude of connecting permutations; however at Barcelona the overall connectivity remained strong as the 
airport was well connected to other major European hubs through other carriers. Suau-Sanchez et al. (2016) researched the connectivity of the UK's regional airports and established that they are largely dependent on traffic emanating to/from foreign hubs.

The number of studies relating to hubbing performance of the major airlines and airports in Asia is fewer than that in Europe. Burghouwt et al. (2009) evaluated the network performance and hub connectivity of the thirteen primary airports in East and Southeast Asia. The study identified Tokyo as the largest hub in terms of connectivity, while the highest growth rates in network development were found at the three major Chinese airports, namely Beijing, Shanghai and Guangzhou. Similarly, Hosombat et al. (2011) measured and compared hub airports in the same region. In this case, however, Hong Kong was identified as the hub leader in the region concerning network connectivity and hub airline development. The study also suggested the intra-Asian route as the stimulus for the hub airport connectivity. De Wit et al. (2007) and Li et al. (2012) focused their research on Japan. While the former analysed the network performance of major airports in Japan and included some airports from Korea, the latter evaluated the dualhub network connectivity of All Nippon Airways at Tokyo's Haneda and Narita airports. The study performed by Li et al. (2012) showed that the adoption of dual-hub strategy supposed a reduction of network connectivity for ANA compared to regional competitors. Meanwhile, Paleari et al. (2010) compared the connectivity offered by the Chinese, EU and US network and found that the Chinese network offers the fastest connections, due to the small number of airports per inhabitants. Furthermore, the study showed that the US network has higher levels of coordination at intermediate airports when compared to the EU network, although the differences of services between major and small airports are more noticeable in the US. Additionally, Redondi et al. (2011) noted that main European airports are favoured by an inherent geographical advantage in relation to world markets compared to American and Asian airports.

The research to date into network performance and hub connectivity has been conducted by a generous body of literature in Europe and Asia - on both sides of the Middle East. However, there is no known study about the networks of the emerging Arabian Gulf carriers. This paper aims to include this region by comparing the hub performance of the three Gulf carriers and to uncover their competitive position against the four major European carriers.

\subsection{Methodology for measuring airline hub performance and competitive position}

According to previous studies (Hanlon, 1989; Bruinsma et al., 2000; Burghouwt et al., 2008; Suau-Sanchez and Burghouwt, 2012; Suau-Sanchez et al., 2016) different measures of hub performance have been developed with reference to this kind of airline network rivalry. Competition between airlines serving two markets via their hub takes place depending on factors such as frequency, ticket prices, travel time, quality of passenger and goods handling, airport facilities or tariffs at the airport.

However, aspects such as airport facilities and handling quality are difficult to evaluate and together with airport tariffs cannot be controlled by the airlines which operate from the hub. Therefore, connectivity and the degree to which a carrier is able to operate effectively in two 
markets via its hub has become an important indicator of competiveness, apart from ticket prices (Hanlon, 1989; Bootsma, 1997; Veldhuis, 1997; Rietveld and Brons, 2001; Burghouwt, 2007; Burghouwt et al., 2008; Suau-Sanchez and Burghouwt, 2012; Suau-Sanchez et al., 2016). Nevertheless, it can generalised that fares are implicitly taken when analysing connectivity as ticket prices fluctuate according to number of competitors on the route and influenced by products such as the quality of connection or the travel time (Burghouwt et al., 2009; SuauSanchez et al., 2016). The principle types of connectivity include direct which mostly captures the local catchment area but whose traffic volumes are often thin and indirect connectivity which predominantly uses sixth freedom traffic rights to aggregate passenger volumes from the multiple spokes to the hub for onward redistribution. This paper focuses exclusively on hub connectivity as it is notably significant for measuring competitiveness of airline hubs (Burghouwt et al., 2009).

The following sections outline the most frequently used connectivity measures used by researchers, after which a weighted indexing connectivity is identified, while the final part of this section gives a detailed description of the dataset that was applied to the research.

\subsection{Hub performance measures}

A wide range of connectivity measures with different levels of complexity can be found in previous studies as shown in Table 1 . The hub potential model and gross vertex connectivity are examples of simple approaches that have been applied. The hub potential model employed by Dennis (1999) considers the product of incoming and outgoing frequencies as a connectivity measure, while the gross vertex connectivity researched by Ivy (1993) and Fik (1995) takes the sum of all indirect connections with three or fewer legs weighted by a scalar number. The shortest path length model is another example of a straightforward method which has been also used in numerous references (Malighetti et al., 2008; Shaw, 1993; Shaw and Ivy, 1994; Cronrath et al., 2008). This model considers the average number of flight stops necessary to get to any other airport in the network. Nevertheless, all the mentioned methods do not consider temporal coordination or the routing factor in their measures, making it difficult to analyse connection quality and hence they have not been considered for this research.

Other more complex models can be identified in the literature. Budde et al. (2008) measure connectivity by analysing the number of statistically significant patterns of arrival and departure waves. In addition, Bootsma (1997) focuses on the number of connections and identifies whether indirect connections respect the MCT and MACT requirements, classifying them in a discrete way as "excellent", "good" or "poor". Similarly, Doganis (1989; 2002) and Dennis (1994a; 2001 ; 1994b) propose a model that shows the degree to which carrier connections that meet MCT and MACT are more than merely random. Nonetheless, in these 3 models the connection detour measure, defined as the routing factor between the great circle distances of the indirect and direct flight, is not taken into account. Although they consider temporal coordination, this research aims to analyse connectivity by studying both the temporal and spatial approach. 
Nevertheless, six more models which consider the temporal and spatial approach were identified. Malighetti et al. (2008) and Paleari et al. (2010) apply the quickest path length model which analyses the average travel time necessary to arrive at any other airport in the network, the number of connections needed on specific O\&D paths as well as routing factors. Additionally, Burghouwt and de Wit (2005) employ the Weighted Number of Connections (WNX) which measures the number of connections weighted by connection quality according to transfer time and detour factor. In the same way, Hub Connectivity Indicator and the Netscan model, used in several references (Burghouwt and Veldhuis, 2006; Veldhuis, 1997; Matsumoto et al., 2008; Airport Council International, 2014) also analyse the number of connections by applying a weight to each of them, but this time according to a ratio between detour time and theoretical direct flight time. Similarly, Lee et al. (2014) use temporal and spatial connectivity measures but also includes a third factor named 'relative' to take into account the influence of direct flight frequency on transfer routes and compare it with other connectivity models. Finally, Danesi (2006) proposes an index which categorises viable connections according to the quality level of their temporal and spatial characteristics.

\section{Insert Table 1}

Although any of the last six methods would be useful for the purpose of evaluating temporal coordination as well as connection detour, this study uses the approach proposed by Danesi (2006) since this method provides slight advantages compared to the others. Although the Quickest Path Length, Continuous Connectivity Index and Netscan model decrease the quality of the connection according to the connecting times, but neither model establishes a specific maximum connecting time. Similarly, the Continuous Connectivity Index and the Netscan model do not have a routing factor upper limit. This implies the need for capturing all the possible connection permutations pertinent for a robust and all-round result. By using Danesi's index called the Weighted Connectivity Ratio, those connections exceeding MACT can be discarded, thus reducing the amount of data to be processed. By applying a threshold of 1.5 to the routing factor, Danesi's model excludes some of the indirect connections offered when the detour is excessive, thus simplifying data processing and omitting highly unlikely connections from the passenger's point of view. These two differences provide Danesi's model with a slight advantage compared to the other two connectivity measures. Furthermore, this approach combines two previous models, namely Doganis and Dennis (1989) Connectivity and Weighted Number of Connections and brings some modifications that improve these two connectivity measures. In addition, Danesi's Weighted Connectivity Ratio introduces the concept of Intermediate Connect Time (ICT).

\subsection{Method}

Considering a time period $T$ which is defined as the daily operational hours of the carrier's hub, let $i=1, \ldots, n_{a}$ be any incoming flight during the time $\mathrm{T}$ and $j=1, \ldots, n_{d}$ any outgoing flight during the same time. Naming the arrival time of flight $i t_{a, i}$ and the departure time of flight $j t_{d, j}$, the connection time between arriving flight $i$ and departing flight $j$ can be defined as $T T_{k}=t_{d, j}-t_{a, i}$, where $k$ is a combination of incoming and outgoing flights $k=(i, j)$. In addition, $n_{a, \text { cont }}$ and $n_{d, \text { cont }}$ 
can be defined as the total number of arriving and departing continental flights respectively. Similarly, $n_{a, i n c}$ and $n_{d, i n c}$ are defined as the total number of incoming and outgoing intercontinental flights throughout the time period $T$. Furthermore, $M C T_{k}$ is defined as the minimum connect time and $M A C T_{k}$ as the maximum acceptable connect time between $i$ and $j$. Additionally, an intermediate connect time $I C T_{k}$ is defined as an intermediate threshold in order to differentiate "rapid connections", $M C T_{k} \leq T T_{k} \leq I C T_{k}$, from other viable but less attractive transfers, $I C T_{k} \leq T T_{k} \leq M A C T_{k}$.

Table 2 shows the MCT, ICT and MACT values considered to carry out the analysis. Although Danesi (2006) proposes more severe level-of-service values, $\mathrm{MACT}_{\mathrm{k}}$ has been increased from 180 minutes to 240 minutes for continental-intercontinental and intercontinental-intercontinental flights more in line with other analyses (Bootsma, 1997; Burghouwt and de Wit, 2005). In line with the study by Seredynski et al. (2014) and by calculating an average OD length of 5,430km from OAG data for the selected carriers, a MACT of 240 minutes would cover more than $80 \%$ of the bookings. The increase of the MACT compared to Danesi's parameters might be translated in slightly higher values regarding temporal connectivity. However, the final weighted connectivity ratio is hardly affected.

\section{Insert Table 2}

Now let the temporal connectivity matrix (TCM) be a matrix with $n_{a}$ rows and $n_{d}$ columns so that any element in it, $\tau_{i j}$, takes one of the following values:

$$
\left\{\begin{array}{ccc}
\tau_{i j}=1 & \text { if } & M C T_{k} \leq T T_{k} \leq I C T_{k} \\
\tau_{i j}=0.5 & \text { if } & I C T_{k}<T T_{k} \leq M A C T_{k} \\
\tau_{i j}=0 & \text { if } & \text { otherwise }
\end{array}\right.
$$

In the same way, let the spatial connectivity matrix (SCM) be a matrix with $n_{a}$ rows and $n_{d}$ columns whose elements, $\delta_{i j}$, take the following values:

$$
\left\{\begin{array}{ccc}
\delta_{i j}=1 & \text { if } & D R_{k} \leq 1.20 \\
\delta_{i j}=0.5 & \text { if } & 1.20<D R_{k} \leq 1.50 \\
\delta_{i j}=0 & \text { if } & \text { otherwise }
\end{array}\right.
$$

where

$$
D R_{k}=\frac{I D_{k}}{D D_{k}}\left(D R_{K} \geq 1\right)
$$

is the detour factor, in which $I D_{k}$ is the sum of great circle distances of the combination $k$ of incoming and outgoing flights and $D D_{k}$ the direct great circle distance between the origin of 
flight $i$ and the destination of flight $j$. Similarly, as according to Seredynski et al. (2014) and considering the same average OD length as earlier, a maximum detour factor of 1.50 would include more than $95 \%$ of the bookings.

Then the weighted connectivity matrix (WCM) is a matrix composed of $n_{a}$ rows and $n_{d}$ columns so that every element in it is:

$$
\omega_{i j}=\tau_{i j} \cdot \delta_{i j}
$$

and any element varies between the following 4 values:

$$
\left\{\begin{aligned}
\omega_{i j}=1.00 & \text { if } & \delta_{i j}=\tau_{i j}=1.0 \\
\omega_{i j}=0.50 & \text { if } & \delta_{i j}+\tau_{i j}=1.5 \\
\omega_{i j}=0.25 & \text { if } & \delta_{i j}=\tau_{i j}=0.5 \\
\omega_{i j}=0.00 & & \text { otherwise }
\end{aligned}\right.
$$

Finally, the weighted connectivity ratio is defined as:

$$
W C R=\frac{W N_{c}}{W N_{r}}
$$

where

$$
W N_{c}=\sum_{i} \sum_{j} \omega_{i j}=\sum_{i} \sum_{j} \tau_{i j} \cdot \delta_{i j}
$$

Is the number of weighted connections offered by the carrier at the hub throughout the time $\mathrm{T}$

$$
\begin{aligned}
W N_{r}= & \frac{\sum_{i} \sum_{j} \delta_{i j}}{n_{a} n_{d}}\left[n_{a, \text { cont }} \frac{n_{d, \text { cont }}}{T}\left(I C T_{1}-M C T_{1}+\frac{M A C T_{1}-I C T_{1}}{2}\right)\right. \\
& +n_{a, \text { cont }} \frac{n_{d, i n c}}{T}\left(I C T_{2}-M C T_{2}+\frac{M A C T_{2}-I C T_{2}}{2}\right) \\
& \left.+n_{a, i n c} \frac{n_{d, i n c}}{T}\left(I C T_{3}-M C T_{3}+\frac{M A C T_{3}-I C T_{3}}{2}\right)\right] \\
& =\frac{\sum_{i} \sum_{j} \delta_{i j}}{n_{a} n_{d}}\left[n_{a, \text { cont }} n_{d, \text { cont }} \frac{M A C T_{1}+I C T_{1}-2 M C T_{1}}{2 T}\right. \\
& +\left(n_{a, \text { cont }} n_{d, \text { inc }}+n_{a, i n c} n_{d, \text { cont }}\right) \frac{M A C T_{2}+I C T_{2}-2 M C T_{2}}{2 T} \\
& \left.\quad+n_{a, i n c} n_{d, \text { inc }} \frac{M A C T_{3}+I C T_{3}-2 M C T_{3}}{2 T}\right]
\end{aligned}
$$

Source: Danesi (2006)

and is the number of weighted connections projected to take place in a random schedule of incoming and outgoing flights during a time period $\mathrm{T}$. 
The weighted connectivity ratio indicates whether the connections are more than merely random by analysing their spatial and temporal characteristics. Given that, weighted connectivity ratios of 1 or less show no schedule coordination at the hub as the available connections at the airport are just a random result of the continuous operation of inbound and outbound flights. By contrast, values greater than 1 indicate some hub schedule coordination and ideally values greater than 2 denote optimal hub connectivity and temporal coordination. In other words, values greater than 2 will imply a connectivity ratio at least two times better than an estimated ratio for a random schedule at the hub.

\subsection{Data description}

Official Airline Guide (OAG) flight schedule data are used as input for the weighted connectivity ratio model. Since the $\mathrm{OAG}$ does not provide realised passenger demand information, it should be pointed out that the analysis is carried out from the supply side. Furthermore, as the methodology selected works on a single-day flight schedule, Thursday $12^{\text {th }}$ June 2014 has been considered as an average weekday outlined in the methodology, proposed by Burghouwt and Redondi (2013). However, it should be noted that by considering one single-day schedule some connections might be not taken into account as the flight frequency might not be daily.

The dataset consists of over 3,700 scheduled non-stop direct flights corresponding to the operations of the seven airlines (EK, EY, QR, LH, KL, AF and BA) considered for the purpose of the study. While EK, EY and QR are the main object of this study, the European airlines LH, $\mathrm{KL}, \mathrm{AF}$ and BA have been chosen as they have been concentrating $60 \%$ of the long-haul activity in Europe at their respective hubs and have represented the main international gateways (Dennis, 2007). It should be highlighted that code shares are not accounted and only connections between flights of the same airline at the hub have been considered for this analysis. The dataset also includes 295 origin and destination airports, over 1,600 routes and more than 280,000 airport pairs with indirect connections across 7 geographical regions (Africa, Asia, Europe, Latin America, North America, the Middle East and Southwest Pacific).

\subsection{Results}

\subsection{Weighted connectivity ratio}

Given the hub schedules of the 7 different airlines shown in the Appendix A, Table 3 reports the results of the analysis using the weighted connectivity ratio presented above and designed to estimate and compare the hub performance of the selected hubs in terms of temporal coordination and spatial connectivity levels.

Insert Table 3 
The results of the analysis show a very high degree of connectivity and temporal coordination for Middle Eastern carriers, clearly greater than European hubs in the case of Qatar Airways and Etihad Airways. With 112 arriving flights and 116 departing flights on the selected date, mostly international - the analysis also demonstrates how Etihad which is the smaller of the three big Gulf carriers can offer a superior weighted connectivity ratio by an adequate timetable coordination and spatial connectivity. While 672.36 weighted connections would occur in the case of a purely random timetable, Etihad is able to offer $1,555.75$ weighted connections at the hub, resulting in a weighted connectivity ratio of 2.31. Qatar Airways also offers a high level of connectivity and temporal coordination according to the criteria explained on section 3.2. With double the continental ${ }^{1}$ flights of Emirates and Etihad Airways, Qatar Airways achieved a weighted connectivity ratio of 2.17 by scheduling 181 arriving flights and 183 departures.

Emirates has the most intercontinental opportunities and has more seat capacity offerings as a result of its larger gauged aircraft, but it does not offer the best temporal co-ordination and connection quality of the Gulf carriers. However, it shows a greater WCR than the European hubbing airlines, which can be explained by the average sector length of the Dubai-based carrier. With an average route distance of 4,597 km, which is $685 \mathrm{~km}$ and 1,357 km greater than Etihad and Qatar Airways respectively, the possibility to connect long-distance flights decreases given that frequencies decline as sector length increases. Therefore, the slightly longer connections combined with a greater $\mathrm{WN}_{\mathrm{r}}$ result in lower WCR compared to $\mathrm{QR}$ and $\mathrm{EY}$. The longer connection time at Dubai has positive ramifications as the longer dwell time though the duty free shops produce additional revenues into the vertically integrated airport/airline administration. In fact Dubai's Duty Free is an important differentiator when compared to the other two Gulf entities, as it is one of the leading airport retailers in the world selling almost US\$2 billion worth of merchandise in 2015 (Dubai Duty Free, 2015). Given the inter-relationship between aviation authorities, airline owners and the airport authorities, this decrease in schedule coordination and connectivity could be induced. As efficient transfers mean fewer chances to use airport retailers (Hanlon, 1989), lower schedule coordination can benefit and enhance non-aeronautical revenue at the hub.

Focusing on the European carriers, Air France shows the highest connectivity and timetable coordination with a weighted connectivity ratio of 1.44 . With the highest number of intercontinental flights from its hub compared to the other airlines, it offers 6,909.75 weighted connections as opposed to $4,812.08$ that would occur in a random schedule with the same number of flights. By contrast, British Airways at London Heathrow shows the lowest level of temporal coordination and connectivity with a weighted connectivity ratio of 1.13 . This can be explained by observing its hub configuration as illustrated in Appendix A, which shows a continuous hub operation for European hubs from early morning till late evening which constrains the operational capability as the airports are closed overnight as opposed to Gulf hubs that have 24-hour service, but during operational hours the EU airports run close to capacity with Heathrow airport at $97 \%$ capacity.

\footnotetext{
${ }^{1}$ In the case of Gulf carriers, it has been considered that continental flights are flights within the Middle East region. In the case of European carriers, continental flights refer to flights within Europe.
} 
Macro factors are also at play as European connectivity is impacted by a widespread footprint of substitute intermodal transportation networks such as high speed trains. In addition the European hubs have large catchment areas of economic wealth with a mature and well established linkage to international markets. In contrast the Gulf hubs are substituting their domestic market shortfall by connecting emerging to emerging markets and emerging to mature markets that are expanding exponentially - these emerging markets have growing populations that are becoming economically wealthier. Data from IATA Economics (2016) shows this impact as the Middle East recorded the world's highest growth rate in International passenger traffic at $11.8 \%$ over a 12 month period ending in May 2016, compared to Europe which registered just 2.1\%.

\subsection{Average connections per arriving flight and routing factors}

Having reported the results of the weighted connectivity ratio which combines the spatial approach with the temporal coordination, it is also interesting to examine each factor separately to visualise their respective importance for the final ratio. Focusing first on the temporal coordination, Table 4 shows the average number of connections per flight and their quality considering the ICT and MACT values as well as the routing factor threshold of 1.5 indicated earlier. While connections with transfer times below 90 minutes in the case of continental connections and 150 minutes for continental-intercontinental and intercontinentalintercontinental are considered as rapid, connections with transfers between these times and 240 minutes are considered slow.

Although the average number of connections per arriving flight $\left(\mathrm{C}_{\mathrm{a}}\right)$ is not itself an appropriate hub temporal co-ordination measure as carriers offering more flights from their hubs would normally show a greater value of $C_{a}$ (Danesi, 2006), the length of these connections is relevant as it makes it possible to measure their quality.

Insert Table 4

Table 4 shows that Etihad Airways and Qatar Airways do not offer a large number of connections per flight arrival, but impressively more than $60 \%$ of their connections are within 150 minutes after the arriving flight. Air France is the third airline offering the best connections per arriving flight with $58.69 \%$ of rapid connections, followed by Lufthansa and KLM with $57.78 \%$ and $52.14 \%$ respectively. Emirates and British Airways fail to achieve 50\% fast connections.

When considering the spatial approach, Qatar Airways and Etihad Airways are once again the best airlines in terms of average routing factor as shown in Table 5. In this case, the Qatar-based carrier shows an excellent positioning in relation to markets served with a detour ratio of 1.11, whereas Etihad Airways is comparatively close with an average routing factor of 1.12. Meanwhile the Dubai-based incumbent makes up for a lower schedule coordination than other 
European airlines by its inherent geographical centrality like the other Gulf carriers with a detour ratio of 1.13. As can be seen in Table 5, the average routing factor is quite similar between the different airlines as this is one of main requirements to efficiently operate as a hub airport. However, European airlines show a slightly higher average routing factor, especially Air France that has a major presence in Latin America, Africa and Asia which results in an increase in its detour ratio.

\section{Insert Table 5}

\subsection{Main competing markets}

The following section focuses on the weighted connectivity results applied to selected traffic flows where both European and Gulf carriers directly compete.

\subsubsection{Europe-Asia}

Table 6 focuses on hub connectivity and temporal coordination between Europe and Asia (which includes the Indian sub continent) pertaining to the Gulf carriers and selected European airlines. Etihad Airways shows the highest degree of connectivity and temporal coordination connecting both regions. With almost $70 \%$ of the average connections being rapid transfers and an average routing factor of 1.13, the Abu Dhabi-based carrier achieves a weighted connectivity ratio of 2.87. Qatar Airways and Emirates are the two next airlines in terms of WCR, outperforming Air France which is the European carrier with the highest weighted connectivity ratio. Although the latter offers a greater percentage of rapid connections, Emirates again takes advantage of its position with an average routing factor of 1.11 compared to 1.25 for Air France.

\section{Insert Table 6}

\subsubsection{North America - Asia}

Table 7 illustrates the hub temporal coordination and connectivity between North America and Asia, which includes the Indian subcontinent, which is a principle target market for the Gulf carriers. Traditionally traffic flows between India and North America moved via EU hubs but it is now being increasingly redirected through the Gulf hubs. When considering traffic flows from South East Asia to the East coast of North America, there are no direct flights so this traffic must go via an intermediate hub. However, the distance and travel time from South East Asia via a Gulf or European hub to the East coast of North America is shorter and consequently takes less travel time to transit through a Gulf or EU hub than taking a Transpacific routing, which creates opportunities for Gulf and European carriers. 
The data concludes that Qatar Airways closely followed by Etihad Airways shows an optimal degree of temporal coordination and connectivity (2.86) by combining fast connections with good positioning in relation to markets served. However in this traffic corridor, Air France surpasses the other carriers in being the third largest airline in terms of WCR with half of its connections below 150 minutes. It should also be noted that although British Airways offers a larger number of connections per arriving flight (5.40) given its huge presence in the North Atlantic market, it only achieves a WCR of 1.18 because of its poor schedule coordination.

Insert Table 7

\subsubsection{Europe - Southwest Pacific}

The Southwest Pacific region is particularly significant for the Gulf carriers whose results are exhibited in Table 8. Emirates' has the highest degree of connectivity and temporal coordination. Offering an average of 4.26 connections per arriving flight, $43.85 \%$ of those below 150 minutes, and an average detour ratio of 1.02, the Dubai-based airline achieves a weighted connectivity ratio of 2.25. Qatar Airways follows with a weighted connectivity ratio of 1.75, with a slightly better routing factor but a lower degree of timetable coordination. Etihad Airways trails the group for the Europe-Southwest Pacific market with a weighted connectivity ratio of 1.44.

\section{Insert Table 8}

\subsection{Conclusion and Recommendations}

The main aim of this research was to assess the hub performance of the three main Gulf carriers, Emirates, Etihad Airways and Qatar Airways, and compare them to the main European hubbing airlines, British Airways, Lufthansa, Air France and KLM. In order to achieve this, an index proposed by Danesi was applied with the goal of analysing the two most essential parameters in analysing the performance of a hub, i.e. schedule coordination and geographical location. The empirical analysis shows a high degree of connectivity and temporal coordination for Gulf carriers, clearly greater than European hubs - Qatar Airways and Etihad Airways provide about twice the level of intercontinental connectivity compared to their European counterparts.

The analysis also demonstrates how Etihad Airways and Qatar Airways, which started from a 'clean sheet of paper' in a fast changing competitive marketplace while void of the legacy shackles endemic in Europe's airlines, offered a high weighted connectivity ratio through an adequate timetable coordination and spatial connectivity. Even though Etihad Airways and Qatar Airways do not offer a large number of connections per flight arrival, more than $60 \%$ of their 
connections are within 150 minutes after the arriving flight. Within the Gulf, Emirates offers the most intercontinental opportunities with high capacity aircraft but has the lower weighted connectivity ratio when compared to the other two Gulf carriers. Although its timetable coordination is lower than Air France, its excellent geographical position captures around 80\% of the world's population who live within an eight-hour flight radius of Dubai, which results in a better weighted connectivity ratio for Emirates when compared to the European legacy carriers.

This research delivers a quantitative approach to hub efficiency which filled a literature gap. The Gulf carriers are structurally changing the flows of international traffic that traditionally had moved through European hubs. The findings support the 2014, ACI Europe Connectivity Report which notes that European hub connectivity is being increasingly challenged by the Gulf based hubs while estimates indicate that the three main Gulf airports provide about twice the level of intercontinental connectivity compared to their European counterparts. The study also analyses hub connectivity for three distinct corridors of traffic flows where Gulf and European hubbing airlines compete and include: Europe-Asia; North America-Asia; and Europe-Southwest Pacific. In the first case, Etihad Airways has the highest degree of connectivity and temporal coordination connecting both Europe and Asia. By contrast, Qatar Airways has the highest connectivity and timetable coordination between North America and Asia. Finally, regarding the Europe-Southwest Pacific traffic flow, Emirates shows the highest degree of timetable coordination and connectivity while there are no European hubbing airlines operating between these two regions. However, it represents an important market for the Gulf carriers which have an excellent routing factor to operate these routes. Eighty three year old Turkish Airlines is currently operating in a different macro environment from the Gulf carriers. It is currently operating in a destabilised political landscape, but benefits from a horizontal air service agreement with the EU, but differentiates from the Gulf carriers as $76 \%$ of its fleet are comprised of narrow body aircraft. Nevertheless Turkish Airlines is also distorting global traffic flows. It has not been considered in this analysis as legacy Western European airlines with well established and mature route networks were specifically compared to the highly disruptive new entrant Gulf carriers - this research gap could be further explored and extrapolated through supplementary investigation.

\section{The Big Picture}

The Gulf countries have positioned aviation very high in its hierarchical roadmap as pivotal to its commercial policies of boosting its economic prosperity which in turn propagates more aviation development and continued growth - it has singularly achieved this through its connectivity model which was visionary given its geocentric location. The Gulf States have built policies that co-support aviation through common governed multifaceted roles among the difference stakeholders making airports act in the interests of airlines for example. Lessons can be learned from such polices - in the UK for example, the lack of vertical governance between airlines and airports, as well as the significant transaction costs of regulation implemented by the CAA, adds layers of complexity and bureaucracy when attempting to induce forward strategic visions and blueprints for future development. Severe Air Passenger Duty taxes imposed by the British 
Government on long haul flights through London Heathrow inflate the ticket tariff escalating the difficulty in competing against other hubs. The Gulf has also invested heavily in airport infrastructure, synchronising it with long haul network development, which remains a myopic entity in the European landscape. As the traditional international traffic flows continue to shift towards the Gulf, this has the dual benefit of alleviating the congestion at European hubs while lowering the environmental impact. The Gulf carriers can accommodate the growth in international air traffic and provide an alternate mechanism to route traffic as European airports reach saturation of their infrastructure. Open skies are a pivotal cornerstone underpinning the accomplishment of connecting hubs that boost economic prosperity and this channel must be championed over regulatory obstacles that restrain countries from being strong economies in a tripartite ensemble of trade, financial services and tourism. IATA (2007) found that a $10 \%$ rise in connectivity, relative to a country's GDP, boosted total factor productivity by almost $1 \%$. The EU need to leap-frog the outdated bilateral agreement protocol and move towards Open Skies mandates coupled with easing the visa restrictions, which would culminate in opening more markets for European hubs and create more opportunities to attract passengers to connect. The EU aviation stakeholders should study the master plan blueprint established by the Gulf States and create world-leading reforms where connectivity is at the heart of transport policy.

\subsection{References}

Airport Council International, 2014. ACI Europe Airport Connectivity Report 2004-2014. Available at: https://www.aci-europe.org/policy/position-papers.html?view= group \&group $=1 \& \mathrm{id}=1$

Amadeus, 2014. Middle East hub airports winning long-haul passenger traffic race. Available at: http://www.amadeus.com/blog/16/04/middle-east-hub-airports-winning-long-haul-passengertraffic-race/

Bel, G., Fageda, X., 2010. Intercontinental flights from European airports: Towards hub concentration or not? International Journal of Transport Economics 37 (2), 133.

Bootsma, P. D., 1997. Airline flight schedule development: analysis and design tools for European hinterland hubs. University of Twente, Utrecht.

Bruinsma, F., Rietveld, P., Brons, M., 2000. Comparative study of hub airports in Europe: Ticket prices, travel time and rescheduling costs. Tijdschrift voor Economische en Sociale Geografie 91 (3), 278-292.

Budde, A., Burghouwt, G., de Wit, J., 2008. Borrowing from behavioural science: a novel method for the analysis of indirect temporal connectivity at airport hubs. Proceedings of the 12th Air Transport Research Society (ATRS) World Conference.

Burghouwt, G., de Wit, J., Veldhuis, J., Matsumoto, H., 2009. Air network performance and hub competitive position: Evaluation of primary airports in East and South-East Asia. Journal of Airport Management 3 (4), 384-400. 
Burghouwt, G., Lieshout, R., Veldhuis, J., 2008. Competition between hub airports: the case of Amsterdam Airport Schiphol. Paper presented ATRS Conference, Athens.

Burghouwt, G., Redondi, R., 2013. Connectivity in air transport networks: an assessment of models and applications. Journal of Transport Economics and Policy 47 (1), 35-53.

Burghouwt, G., Veldhuis, J., 2006. The competitive position of hub airports in the transatlantic market. Journal of Air Transportation 11 (1).

Burghouwt, G., 2007. Airline network development in Europe and its implications for airport planning. Ashgate, Aldershot.

Burghouwt, G., de Wit, J., 2005. Temporal configurations of European airline networks. Journal of Air Transport Management 11 (3), 185-198.

Cronrath, E., Arndt, A., Zoch, A., 2008. Does size matter? The importance of airports in the European and German air transport network. Proceedings of the Air Transport Research Society Conference, Athens.

Danesi, A., 2006. Measuring airline hub timetable co-ordination and connectivity: definition of a new index and application to a sample of European hubs. European Transport 34, 54-74.

Delfmann, W., Baum, H., Auerbach, S., Albers, S., 2005. Moving Targets: Strategic Trends in the Aviation Sector, in Delfmann, W., Baum, H., Auerbach, S., et al (eds.) Strategic Management in the Aviation Industry. Ashgate, Aldershot, 1-15.

Dennis, N., 1994a. Airline hub operations in Europe. Journal of Transport Geography 2 (4), 219233.

Dennis, N., 1994b. Scheduling strategies for airline hub operations. Journal of Air Transport Management 1 (3), 131-144.

Dennis, N., 2001. Developments of hubbing at European airports. Air \& Space Europe 3 (1-2), 51-55.

Dennis, N., 2007. Competition and Change in the Long-Haul Markets from Europe. Journal of Air Transportation 12 (2), 4-26.

Dennis, N., 1999. Competition between hub airports in Europe and a methodology for forecasting connecting traffic. World transport research: proceedings 1 .

de Wit, J., 2014. Unlevel playing field? Ah yes, you mean protectionism. Journal of Air Transport Management, 41, 22-29.

Doganis, R., Dennis, N., 1989. Lessons in hubbing. Airline Business March 1989, $42-47$.

Doganis, R., 2002. Flying off course: the economics of international airlines. Routledge, London. 
Dubai Duty Free, 2015. Dubai Duty Free Group Sales Reach US\$1.933 billion in 2015, accessed at http://www.dubaidutyfree.com/media_center/news_detail/657/ Dubai-Duty-Free-GroupSales-Reach-Dhs7.057-billion-US1.933-billion-in-2015

Dresner, M., Eroglu, C., Hofer, C., Mendez, F., Tan, K., 2015. The impact of Gulf carrier competition on U.S. airlines. Transportation Research Part A: Policy and Practice, 79, 31-41.

Fan, T.P.C., Lingblad, M., 2016. Thinking through the meteoric rise of Middle-East carriers from Singapore Airlines' vantage point. Journal of Air Transport Management, 54, 111-122.

Fik, T., Ivy, R., Malecki, E., 1995. Changes in air service connectivity and employment. Environment and Planning A 27 (2), 165-179.

Flightglobal, 2016. Subscription publication, accessed at https://www.flightglobal.com

Goedeking, P., 2010. Networks in aviation: strategies and structures. Springer, Heidelberg.

Grimme, W., 2011. The growth of Arabian airlines from a German perspective - A study of the impacts of new air services to Asia. Journal of Air Transport Management 17 (6), 333-338.

Grosche, T., Klophaus, R., 2015. Hubs at risk: Exposure of Europe's largest hubs to competition on transfer city Pairs. Transport Policy, 43, 55-60.

Hanlon, J. P., 1989. Hub operations and airline competition. Tourism Management 10 (2), 111124.

Hooper, P., Walker, S., Moore, C., Al Zubaidi, Z., 2011. The development of the Gulf region's air transport networks - The first century. Journal of Air Transport Management 17 (6), 325-332.

Hosombat, W., Lei, Z., Fu, X., 2011. Development status and prospects for aviation hubs - A comparative study of the major airports in South-East Asia. The Singapore Economic Review 56 (4), 573-591.

IATA Economics, 2016. Air Passenger Market Analysis, May, accessed at http://www.iata.org/whatwedo/Documents/economics/passenger-analysis-may-2016.pdf

IATA, 2007. Aviation Economic Benefits, IATA Economic Briefing, No 8, accessed at https://www.iata.org/whatwedo/Documents/economics/aviation_economic_benefits.pdf

Ivy, R. L., 1993. Variations in hub service in the US domestic air transportation network. Journal of Transport Geography 1 (4), 211-218.

J.G. de Wit, J.G. Veldhuis, G. Burghouwt and H. Matsumoto, 2007. Measuring and comparing the network performance of four major airports in Japan and Korea: which airport is the primary hub to Japan?. Higashiajia e no Shiten 18 (4), 25-36.

Lee, S. Y., Yoo, K. E., Park, Y., 2014. A Continuous Connectivity Model for Evaluating of Huband-Spoke Operations. Transportmetrica A: Transport Science, 1-23. 
Li, W. K., Miyoshi, C., Pagliari, R., 2012. Dual-hub network connectivity: An analysis of all Nippon Airways' use of Tokyo's Haneda and Narita airports. Journal of Air Transport Management 23 (1), 12-16.

Lipovich, G. A., 2012. La calidad de los hubs de América Latina. Journal of Transport Literature $6(2), 144-168$.

Malighetti, P., Paleari, S., Redondi, R., 2008. Connectivity of the European airport network: "Self-help hubbing" and business implications. Journal of Air Transport Management 14 (2), 5365 .

Matsumoto, H., Veldhuis, J., de Wit, J., Burghouwt, G., 2008. Network performance, hub connectivity potential, and competitive position of primary airports in Asia/Pacific region. Proceedings of the Air Transport Research Society Conference, Athens (10.06.08).

Murel, M., O'Connell, J. F., 2011. Potential for Abu Dhabi, Doha and Dubai Airports to reach their traffic objectives. Research in Transportation Business \& Management 1 (1), 36-46.

OAG, 2015. Delivering Passengers: Gulf Carriers Importance for US Airlines, accessed at http://www.oag.com/blog/delivering-passengers-gulf-carriers-importance-us-airlines

O'Connell, J. F., 2006. The changing dynamics of the Arab Gulf based airlines and an investigation into the strategies that are making Emirates into a global challenger. World Review of Intermodal Transportation Research 1 (1), 94-114.

O'Connell, J. F., 2011. The rise of the Arabian Gulf carriers: An insight into the business model of Emirates Airline. Journal of Air Transport Management 17 (6), 339-346.

Paleari, S., Redondi, R., Malighetti, P., 2010. A comparative study of airport connectivity in China, Europe and US: Which network provides the best service to passengers?. Transportation Research Part E: Logistics and Transportation Review 46 (2), 198-210.

Redondi, R., Malighetti, P., Paleari, S., 2011. Hub competition and travel times in the worldwide airport network. Journal of Transport Geography 19 (6), 1260-1271.

Rietveld, P., Brons, M., 2001. Quality of hub-and-spoke networks; the effects of timetable coordination on waiting time and rescheduling time. Journal of Air Transport Management 7 (4), 241-249.

Suau-Sanchez, P., Burghouwt, G., 2012. Connectivity levels and the competitive position of Spanish airports and Iberia's network rationalization strategy, 2001-2007, Journal of Air Transport Management, 18(1), 47-53.

Suau-Sanchez, P., Voltes-Dorta, A., Rodríguez-Déniz, H., 2016. The role of London airports in providing connectivity for the UK: regional dependence on foreign hubs, Journal of Transport Geography, 50, 94-104. 
Seredynski, A., Rothlauf, F., Grosche, T., 2014. An airline connection builder using maximum connection lag with greedy parameter selection. Journal of Air Transport Management 36, 120128.

Shaw, S., 1993. Hub structures of major US passenger airlines. Journal of Transport Geography $1(1), 47-58$.

Shaw, S., Ivy, R. L., 1994. Airline mergers and their effect on network structure. Journal of Transport Geography 2 (4), 234-246.

UK CAA, 2015. Data and Analysis, accessed at https://www.caa.co.uk/Data-and-analysis/

Veldhuis, J., 1997. The competitive position of airline networks. Journal of air transport management 3 (4), 181-188.

Vespermann, J., Wald, A., Gleich, R., 2008. Aviation growth in the Middle East - impacts on incumbent players and potential strategic reactions. Journal of Transport Geography 16 (6), 388394.

Appendix A. Hub configurations

Insert Figure 1

Insert Figure 2

Insert Figure 3

Insert Figure 4

Insert Figure 5

Insert Figure 6

Insert Figure 7 
Table 1. Connectivity measures, main references and characteristics

\begin{tabular}{|c|c|c|c|c|}
\hline Model & Main references & $\begin{array}{l}\text { Temporal } \\
\text { coordination }\end{array}$ & $\begin{array}{l}\text { Routing } \\
\text { factor }\end{array}$ & $\begin{array}{l}\text { Connection } \\
\text { quality }\end{array}$ \\
\hline Hub potential & Dennis (1998) & No & No & No \\
\hline $\begin{array}{l}\text { Gross vertex } \\
\text { connectivity }\end{array}$ & Ivy (1993); Fik (1995) & No & No & No \\
\hline Shortest path length & $\begin{array}{l}\text { Shaw (1993); Shaw and Ivy (1994); } \\
\text { Cronrath et al. (2008); Malighetti et } \\
\text { al. (2008) }\end{array}$ & No & No & Binary \\
\hline $\begin{array}{l}\text { Number of connection } \\
\text { patterns }\end{array}$ & Budde et al. (2008) & Yes & No & Binary \\
\hline Bootsma connectivity & Bootsma (1997) & Yes & No & Discrete \\
\hline $\begin{array}{l}\text { Doganis and Dennis } \\
\text { connectivity }\end{array}$ & $\begin{array}{l}\text { Doganis (1989); Doganis (2002); } \\
\text { Dennis (1994a); Dennis (1994b); } \\
\text { Dennis (2001); Lee et al. (2014) }\end{array}$ & Yes & No & Binary \\
\hline Quickest path length & $\begin{array}{l}\text { Malighetti et al. (2008); Paleari et al. } \\
(2010)\end{array}$ & Yes & Yes & Binary \\
\hline $\begin{array}{l}\text { Weighted Number of } \\
\text { Connections (WNX) }\end{array}$ & $\begin{array}{l}\text { Burghouwt and de Wit (2005); } \\
\text { Lipovich, (2012) }\end{array}$ & Yes & Yes & Continuous \\
\hline $\begin{array}{l}\text { Netscan Connectivity } \\
\text { Units (CNU) }\end{array}$ & $\begin{array}{l}\mathrm{ACl}(2014) \text {; Veldhuis (1997); } \\
\text { Burghouwt and Veldhuis (2006); } \\
\text { Matsumoto et al. (2008) }\end{array}$ & Yes & Yes & Continuous \\
\hline $\begin{array}{l}\text { Continuous } \\
\text { Connectivity } \\
\text { Index }(\mathrm{CCl})\end{array}$ & Lee et al. (2014) & Yes & Yes & Continuous \\
\hline $\begin{array}{l}\text { Hub Connectivity } \\
\text { Indicator }(\mathrm{HCl})\end{array}$ & Li et al. (2012) & Yes & Yes & Continuous \\
\hline $\begin{array}{l}\text { Danesi connectivity - } \\
\text { Weighted Connectivity } \\
\text { Ratio (WCR) }\end{array}$ & Danesi (2006); Lee et al. (2014) & Yes & Yes & Discrete \\
\hline
\end{tabular}

Source: adapted from Burghouwt and Redondi, 2013

Table 2. Values of MCT, ICT and MACT taken for the calculation of weighted connectivity ratio

\begin{tabular}{lccc}
\hline Connection type & $\mathbf{M C T}_{\mathbf{k}}$ & $\mathbf{I C T}_{\mathbf{k}}$ & $\mathbf{M A C T}_{\mathbf{k}}$ \\
\hline Continental-Continental & 45 & 90 & 240 \\
Continental-Intercontinental & 60 & 150 & 240 \\
Intercontinental-Intercontinental & 60 & 150 & 240 \\
\hline \hline
\end{tabular}

Source: Danesi (2006) modified by the authors 
Table 3. Daily number of arriving flights and departing flights, number of weighted connections $\left(\mathbf{W N}_{\mathrm{c}}\right)$, random weighted connections $\left(W_{\mathrm{r}}\right)$ and weighted connectivity ratio (WCR) for selected airlines on Thursday $12^{\text {th }}$ June 2014

\begin{tabular}{lllllllllll}
\hline Airline & Hub & $\mathbf{n}_{\mathrm{a}, \text { cont }}$ & $\mathbf{n}_{\mathrm{d}, \text { cont }}$ & $\mathbf{n}_{\mathrm{a}, \text { int }}$ & $\mathbf{n}_{\mathrm{d}, \text { int }}$ & $\mathbf{n}_{\mathrm{a}}$ & $\mathbf{n}_{\mathrm{d}}$ & $\mathbf{W N}_{\mathbf{c}}$ & $\mathbf{W N}_{\mathbf{r}}$ & $\mathbf{W C R}$ \\
\hline Etihad Airways & AUH & 30 & 30 & 82 & 86 & 112 & 116 & $1,555.75$ & 672.36 & $\mathbf{2 . 3 1}$ \\
Qatar Airways & DOH & 60 & 61 & 121 & 122 & 181 & 183 & $1,676.50$ & 771.67 & $\mathbf{2 . 1 7}$ \\
Emirates & DXB & 27 & 27 & 162 & 162 & 189 & 189 & $2,640.75$ & $1,793.77$ & $\mathbf{1 . 4 7}$ \\
Air France & CDG & 237 & 237 & 92 & 95 & 329 & 332 & $6,909.75$ & $4,812.08$ & $\mathbf{1 . 4 4}$ \\
KLM & AMS & 265 & 264 & 56 & 52 & 321 & 316 & $9,476.25$ & $7,209.25$ & $\mathbf{1 . 3 1}$ \\
Lufthansa & FRA & 358 & 356 & 68 & 69 & 426 & 425 & $15,938.50$ & $12,778.00$ & $\mathbf{1 . 2 5}$ \\
British Airways & LHR & 222 & 234 & 92 & 91 & 314 & 325 & $8,011.00$ & $7,106.52$ & $\mathbf{1 . 1 3}$ \\
\hline \hline
\end{tabular}

Source: Compiled by authors

Table 4. Average number of connections per arriving flight at the hubs of the selected airlines on $12^{\text {th }}$ June 2014

\begin{tabular}{|c|c|c|c|c|c|c|}
\hline \multirow[t]{2}{*}{ Airline } & \multirow[t]{2}{*}{ Hub } & \multirow{2}{*}{$\begin{array}{l}\text { Average total } \\
\text { connections per } \\
\text { arriving flight } \\
\left(C_{a}\right)\end{array}$} & \multicolumn{2}{|c|}{$\begin{array}{l}\text { Average rapid connections per } \\
\text { arriving flight }\end{array}$} & \multicolumn{2}{|c|}{$\begin{array}{l}\text { Average slow connections } \\
\text { per arriving flight }\end{array}$} \\
\hline & & & No. & Percentage & No. & Percentage \\
\hline Etihad Airways & $\mathrm{AUH}$ & 18.85 & 12.43 & $65.94 \%$ & 6.42 & $34.06 \%$ \\
\hline Qatar Airways & $\mathrm{DOH}$ & 12.99 & 7.94 & $61.12 \%$ & 5.05 & $38.88 \%$ \\
\hline Air France & CDG & 37.45 & 21.98 & $58.69 \%$ & 15.47 & $41.31 \%$ \\
\hline Lufthansa & FRA & 55.41 & 30.35 & $54.78 \%$ & 25.06 & $45.22 \%$ \\
\hline KLM & AMS & 44.57 & 23.24 & $52.14 \%$ & 21.33 & $47.85 \%$ \\
\hline Emirates & DXB & 21.02 & 10.40 & $49.50 \%$ & 10.6 & $50.50 \%$ \\
\hline British Airways & LHR & 39.25 & 18.55 & $47.26 \%$ & 20.70 & $52.74 \%$ \\
\hline
\end{tabular}

Source: Compiled by authors

Table 5. Average routing factor

\begin{tabular}{lll}
\hline Airline & Hub & Average routing factor \\
\hline Qatar Airways & DOH & 1.11 \\
Etihad Airways & AUH & 1.12 \\
Emirates & DXB & 1.13 \\
British Airways & LHR & 1.14 \\
KLM & AMS & 1.14 \\
Lufthansa & FRA & 1.14 \\
Air France & CDG & 1.25 \\
\hline \hline
\end{tabular}

Source: Compiled by authors 
Table 6. Hub connectivity and temporal coordination between Europe and Asia for selected airlines on $12^{\text {th }}$ June 2014

\begin{tabular}{|c|c|c|c|c|c|c|c|c|}
\hline \multirow[t]{2}{*}{ Airline } & \multirow[t]{2}{*}{ Hub } & \multirow[t]{2}{*}{$\begin{array}{l}\text { Average } \\
\text { connections } \\
\text { per arriving } \\
\text { flight }\end{array}$} & \multicolumn{2}{|c|}{$\begin{array}{l}\text { Average rapid } \\
\text { connections per } \\
\text { arriving flight }\end{array}$} & \multicolumn{2}{|c|}{$\begin{array}{l}\text { Average slow } \\
\text { connections per } \\
\text { arriving flight }\end{array}$} & \multirow[t]{2}{*}{$\begin{array}{l}\text { Average } \\
\text { routing } \\
\text { factor }\end{array}$} & \multirow[t]{2}{*}{ WCR } \\
\hline & & & No. & Percentage & No. & Percentage & & \\
\hline $\begin{array}{l}\text { Etihad } \\
\text { Airways }\end{array}$ & $\mathrm{AUH}$ & 10.00 & 6.98 & $69.85 \%$ & 3.02 & $30.15 \%$ & 1.13 & 2.87 \\
\hline $\begin{array}{l}\text { Qatar } \\
\text { Airways }\end{array}$ & $\mathrm{DOH}$ & 10.00 & 6.17 & $61.68 \%$ & 3.83 & $38.32 \%$ & 1.11 & 1.82 \\
\hline Emirates & DXB & 13.56 & 6.23 & $45.90 \%$ & 7.34 & $54.10 \%$ & 1.11 & 1.61 \\
\hline Air France & CDG & 22.43 & 10.51 & $46.84 \%$ & 11.92 & $53.16 \%$ & 1.25 & 1.31 \\
\hline Lufthansa & FRA & 42.37 & 21.40 & $50.49 \%$ & 20.98 & $49.51 \%$ & 1.15 & 1.17 \\
\hline KLM & AMS & 8.89 & 4.27 & $47.99 \%$ & 4.63 & $52.01 \%$ & 1.22 & 1.17 \\
\hline $\begin{array}{l}\text { British } \\
\text { Airways }\end{array}$ & LHR & 22.68 & 8.56 & $37.73 \%$ & 14.13 & $62.27 \%$ & 1.16 & 1.01 \\
\hline
\end{tabular}

Source: Compiled by authors

Table 7. Hub connectivity and temporal coordination between North America and Asia for selected airlines on $12^{\text {th }}$ June 2014

\begin{tabular}{|c|c|c|c|c|c|c|c|c|}
\hline \multirow[t]{2}{*}{ Airline } & \multirow[t]{2}{*}{ Hub } & \multirow[t]{2}{*}{$\begin{array}{l}\text { Average } \\
\text { connections } \\
\text { per arriving } \\
\text { flight }\end{array}$} & \multicolumn{2}{|c|}{$\begin{array}{l}\text { Average rapid } \\
\text { connections per } \\
\text { arriving flight }\end{array}$} & \multicolumn{2}{|c|}{$\begin{array}{l}\text { Average slow } \\
\text { connections per } \\
\text { arriving flight }\end{array}$} & \multirow[t]{2}{*}{$\begin{array}{l}\text { Average } \\
\text { routing } \\
\text { factor }\end{array}$} & \multirow[t]{2}{*}{ WCR } \\
\hline & & & No. & Percentage & No. & Percentage & & \\
\hline $\begin{array}{l}\text { Qatar } \\
\text { Airways }\end{array}$ & $\mathrm{DOH}$ & 3.90 & 2.42 & $62.17 \%$ & 1.47 & $37.83 \%$ & 1.12 & 2.86 \\
\hline $\begin{array}{l}\text { Etihad } \\
\text { Airways }\end{array}$ & $\mathrm{AUH}$ & 3.98 & 2.13 & $53.55 \%$ & 1.85 & $46.45 \%$ & 1.16 & 2.76 \\
\hline Air France & CDG & 2.65 & 1.35 & $50.94 \%$ & 1.30 & $49.06 \%$ & 1.27 & 1.40 \\
\hline Emirates & DXB & 3.10 & 1.50 & $48.39 \%$ & 1.60 & $51.61 \%$ & 1.18 & 1.35 \\
\hline Lufthansa & FRA & 3.26 & 1.38 & $42.52 \%$ & 1.87 & $57.48 \%$ & 1.19 & 1.26 \\
\hline $\begin{array}{l}\text { British } \\
\text { Airways }\end{array}$ & LHR & 5.40 & 2.26 & $41.88 \%$ & 3.14 & $58.12 \%$ & 1.15 & 1.19 \\
\hline KLM & AMS & 0.45 & 0.13 & $28.57 \%$ & 0.32 & $71.43 \%$ & 1.32 & 1.18 \\
\hline
\end{tabular}

Source: compiled by authors 
Table 8. Hub connectivity and temporal coordination between Europe and Southwest Pacific for selected airlines on $12^{\text {th }}$ June 2014

\begin{tabular}{|c|c|c|c|c|c|c|c|c|}
\hline \multirow[t]{2}{*}{ Airline } & \multirow[t]{2}{*}{ Hub } & \multirow{2}{*}{$\begin{array}{l}\text { Average } \\
\text { connections } \\
\text { per arriving } \\
\text { flight }\end{array}$} & \multicolumn{2}{|c|}{$\begin{array}{l}\text { Average rapid } \\
\text { connections per } \\
\text { arriving flight }\end{array}$} & \multicolumn{2}{|c|}{$\begin{array}{l}\text { Average slow } \\
\text { connections per } \\
\text { arriving flight }\end{array}$} & \multirow[t]{2}{*}{$\begin{array}{l}\text { Average } \\
\text { routing } \\
\text { factor }\end{array}$} & \multirow[t]{2}{*}{ WCF } \\
\hline & & & No. & Percentage & No. & Percentage & & \\
\hline Emirates & DXB & 4.26 & 1.87 & $43.85 \%$ & 2.39 & $56.15 \%$ & 1.02 & 2.25 \\
\hline $\begin{array}{l}\text { Qatar } \\
\text { Airways }\end{array}$ & $\mathrm{DOH}$ & 1.09 & 0.45 & $41.17 \%$ & 0.64 & $58.83 \%$ & 1.01 & 1.75 \\
\hline $\begin{array}{l}\text { Etihad } \\
\text { Airways }\end{array}$ & $\mathrm{AUH}$ & 2.62 & 1.69 & $64.71 \%$ & 0.92 & $35.29 \%$ & 1.06 & 1.44 \\
\hline
\end{tabular}

Source: compiled by authors

Figure 1. Hub configuration for Emirates at Dubai International Airport

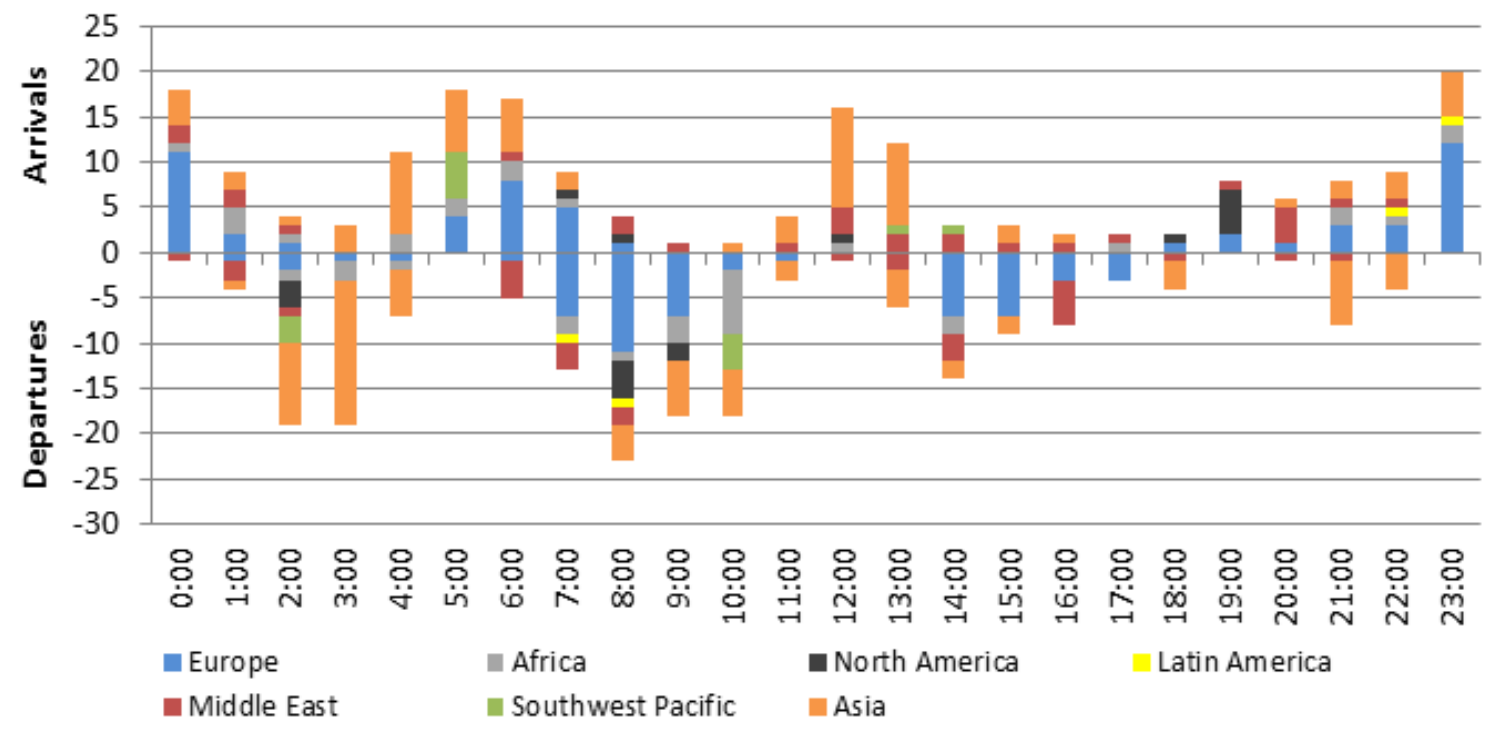

Source: OAG 
Figure 2. Hub configuration for Etihad Airways at Abu Dhabi International Airport

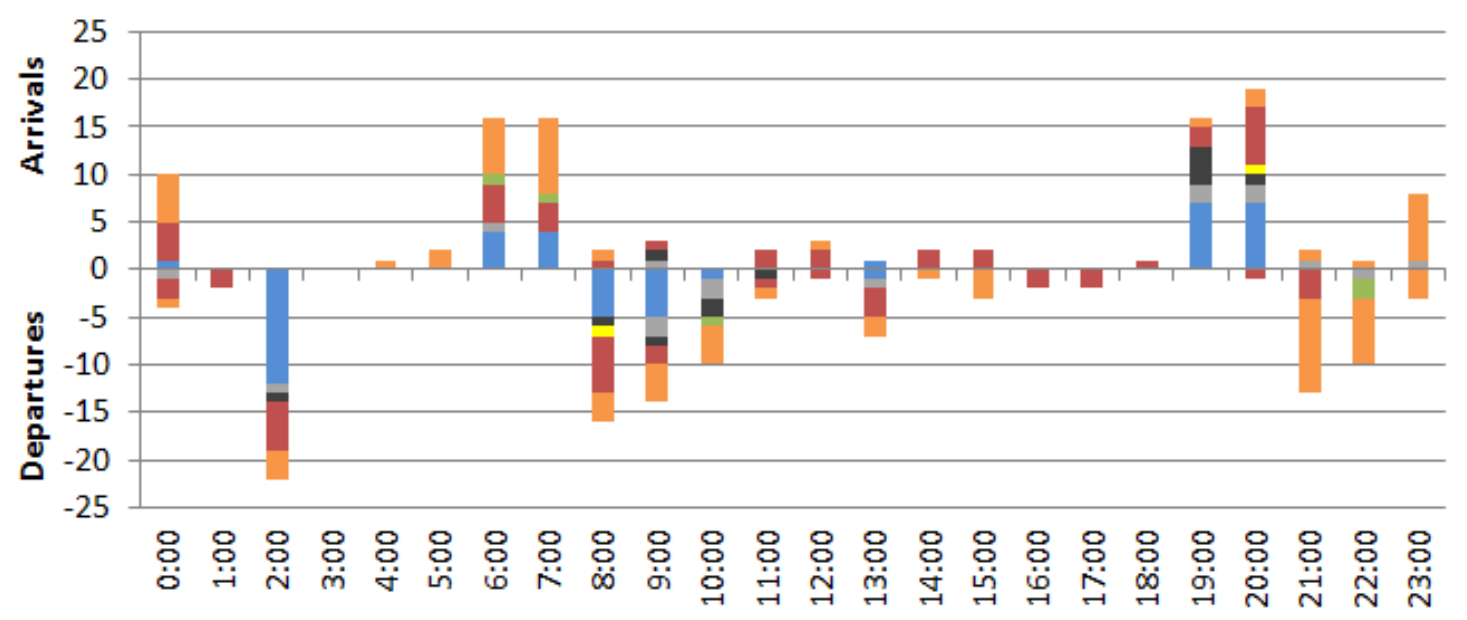

$$
\begin{aligned}
& \text { Europe } \quad \text { Africa North America } \quad \text { Latin America } \quad \text { Middle East } \\
& \text { m Southwest Pacific } \square \text { Asia }
\end{aligned}
$$

Source: OAG

Figure 3. Hub configuration for Qatar Airways at Hamad International Airport

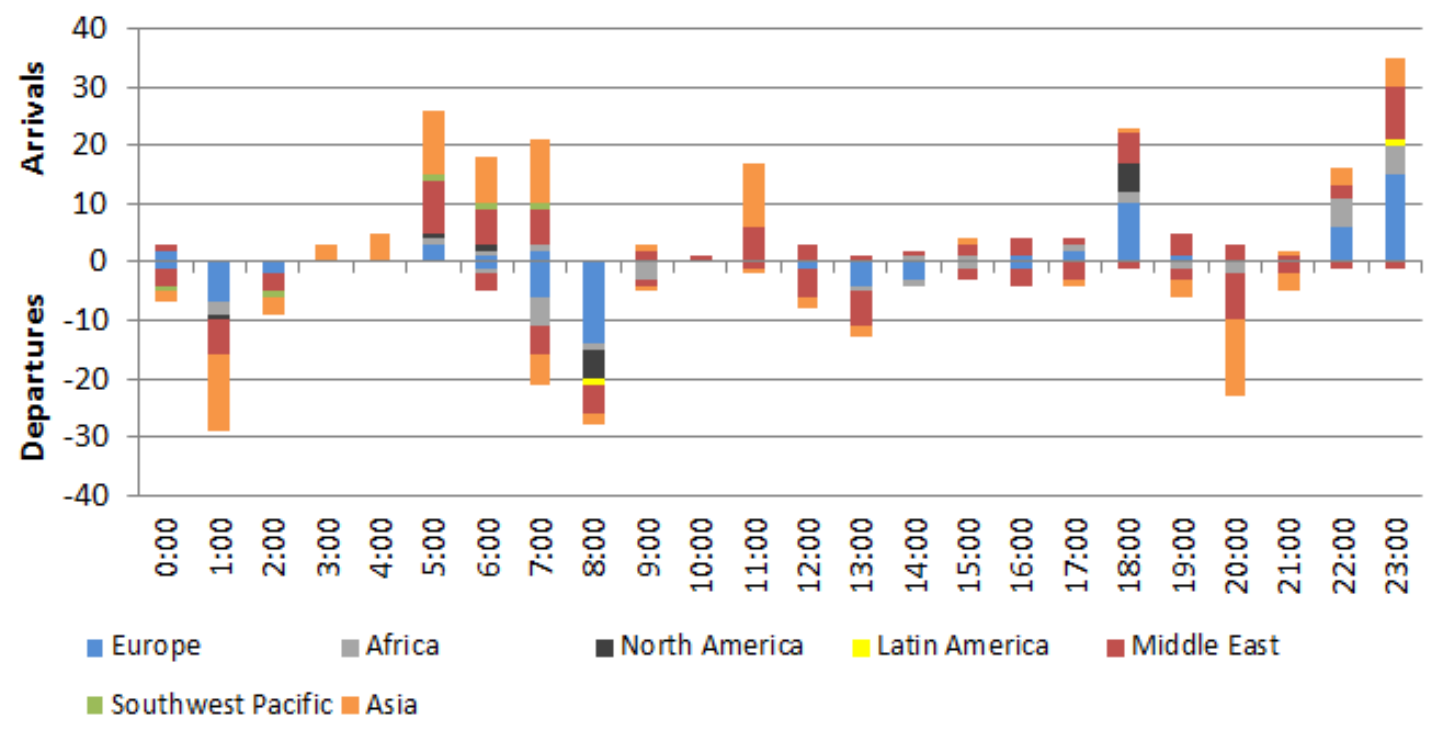

Source: OAG 
Figure 4. Hub configuration for British Airways at London Heathrow Airport

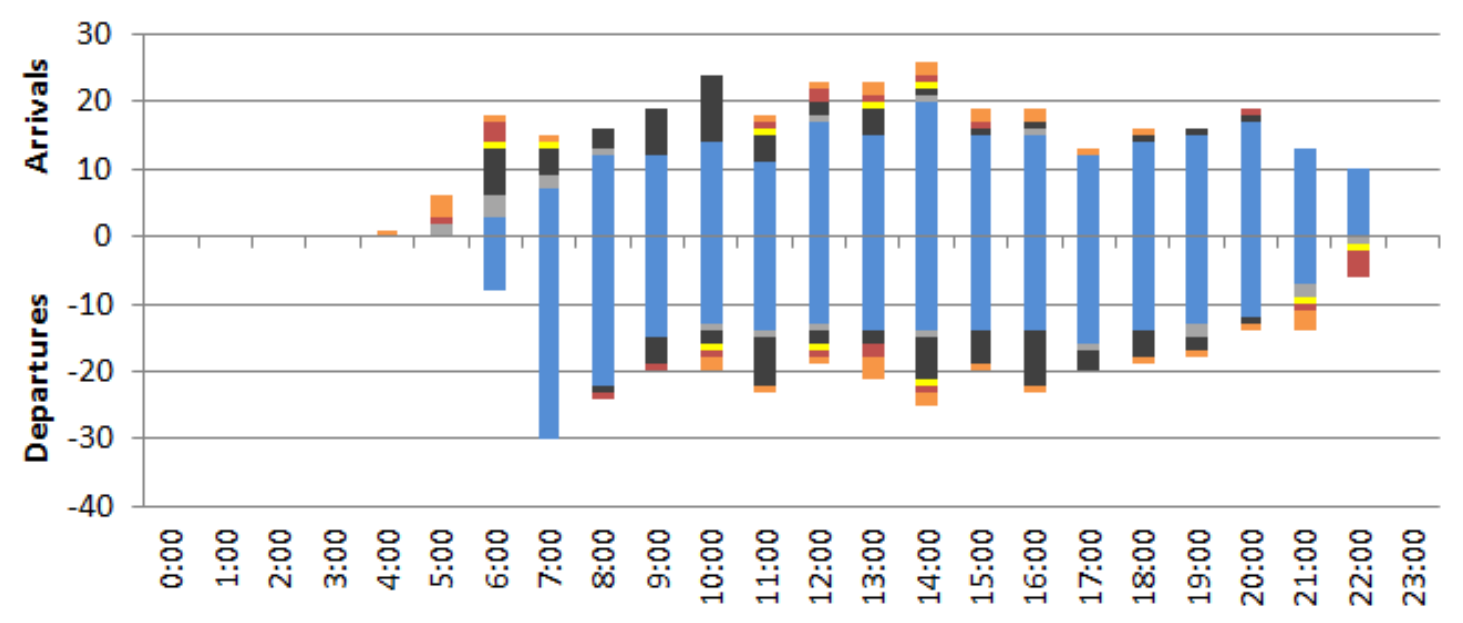

Europe $\quad$ Africa North America $\square$ Latin America $\square$ Middle East

nouthwest Pacific $\square$ Asia

Source: OAG

Figure 5. Hub configuration for Lufthansa at Frankfurt Airport

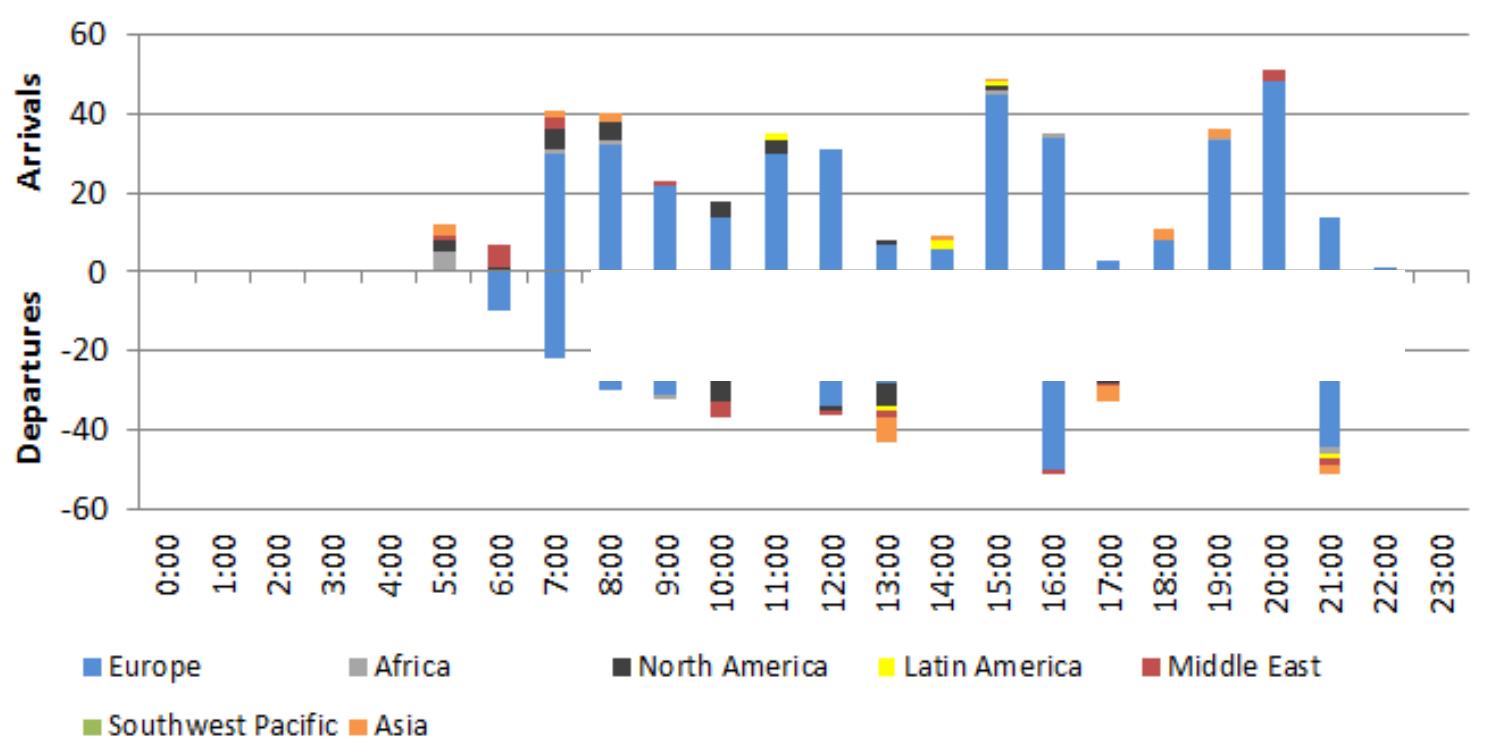

Source: OAG 
Figure 6. Hub configuration for Air France at Paris Charles de Gaulle Airport

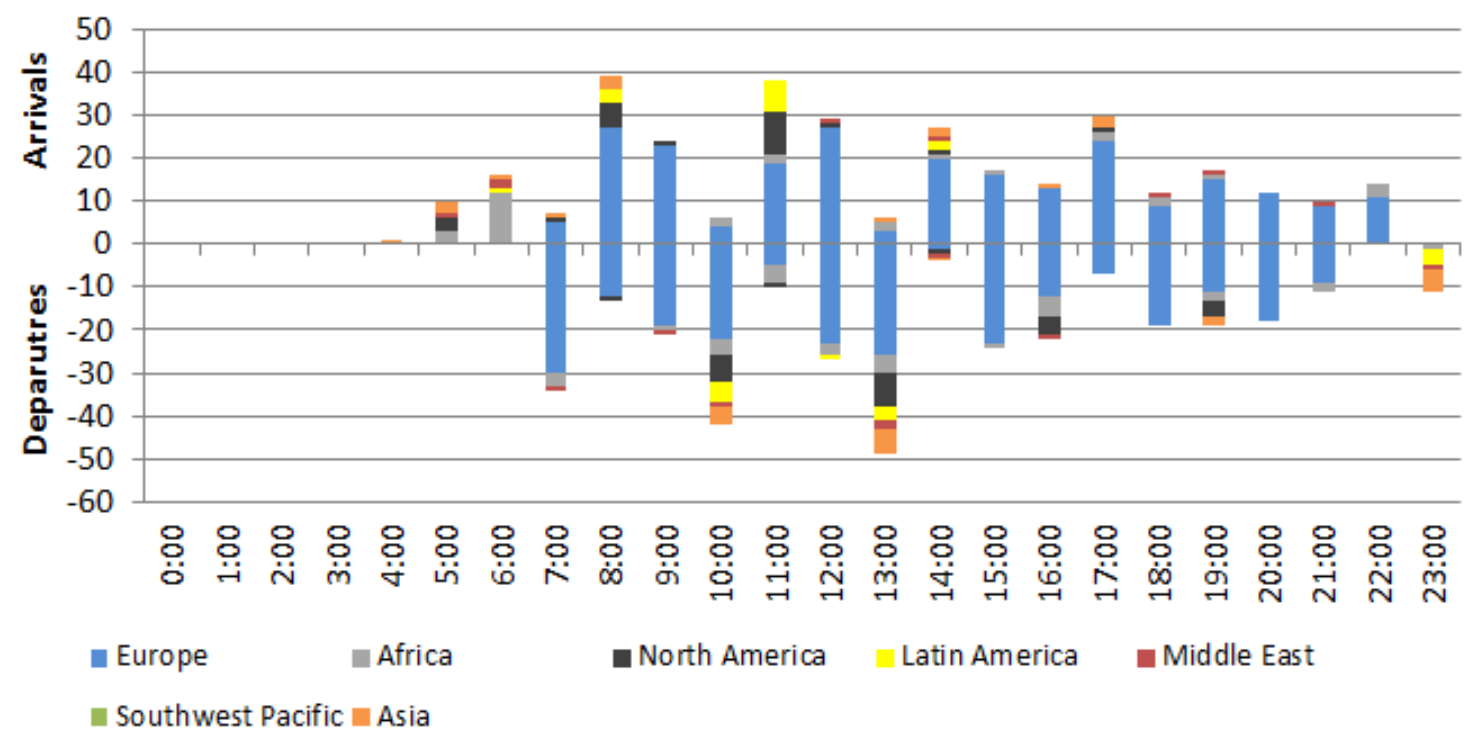

Source: OAG

Figure 7. Hub configuration for KLM Royal Dutch Airlines at Amsterdam-Schiphol Airport

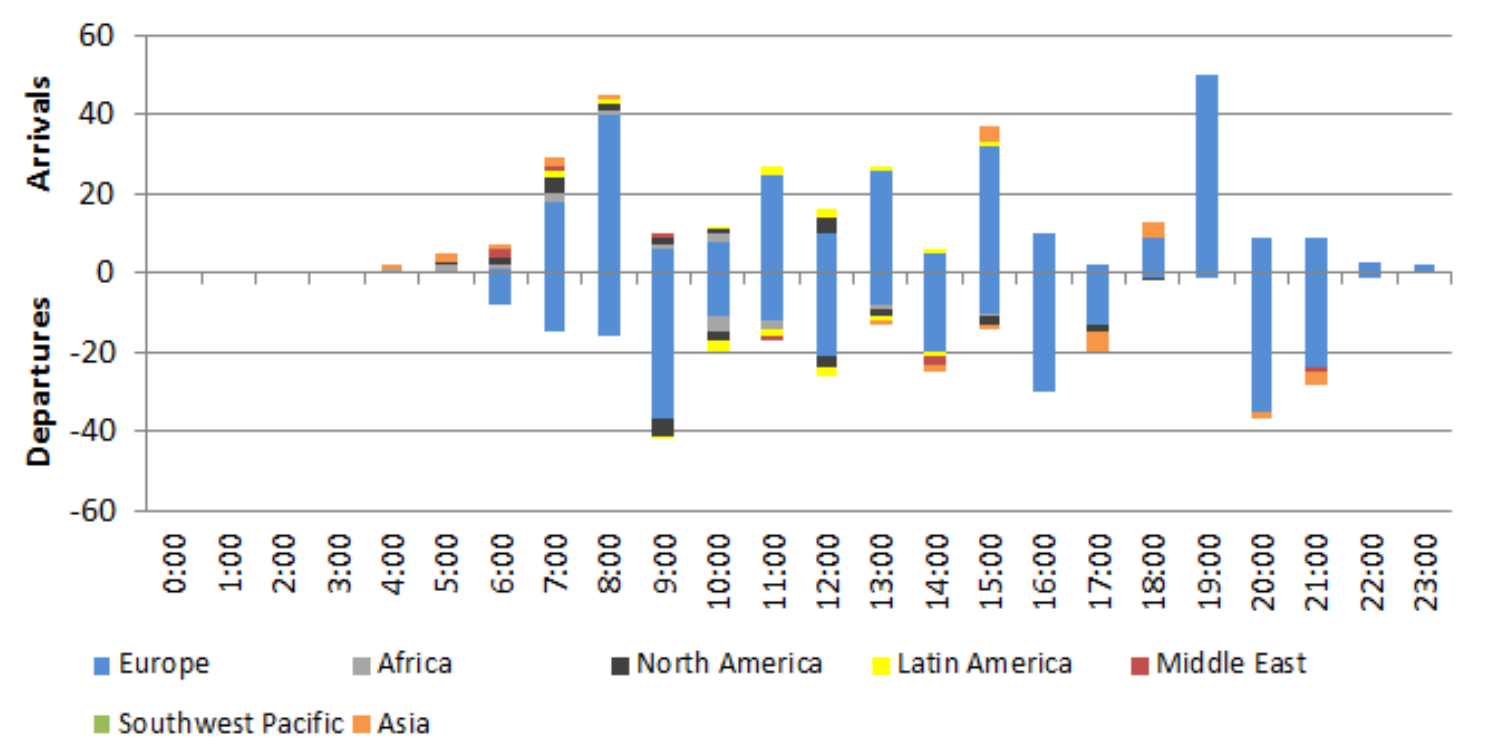

Source: OAG 


\section{A study into the hub performance}

Emirates, Etihad Airways and Qatar

Airways and their competitive position against the major European hubbing airlines

O'Connell, John F.

Elsevier

O'Connell JF, Bueno OE. A study into the hub performance of Emirates, Etihad Airways and Qatar Airways and their competitive position against the major European hubbing airlines. Journal of Air Transport Management, Volume 69, June 2018, pp. 257-268

http://dx.doi.org/10.1016/j.jairtraman.2016.11.006

Downloaded from Cranfield Library Services E-Repository 